\title{
A Hill Full of Points in Terra Incognita from Patagonia: Notes and Reflections for Discussing the Way and Tempo of Initial Peopling
}

\section{Laura Miotti and Enrique Terranova}

\author{
Universidad Nacional de La Plata, Argentina
}

We present the environmental and archeological results of research at Cerro Amigo Oeste, a mesa-top archeological site with Fishtail points located on the Somuncurá Plateau, northern Patagonia, Argentina. Comparison with other South American sites is used to interpret archeological landscapes of colonization. The objects, features, and beings of landscape are understood as reflecting the materiality of social relations as well as patterns of production, retooling, and mobility. Cerro Amigo Oeste is in a very special location due to its high elevation and extensive view of the landscape, as well as its archeological and ethnographic significance. It can be considered a node or hub of communication in the social network among hunter-gatherers far and near in the late Pleistocene.

Keywords American peopling, archeological landscapes, social agency, Fishtail points

"Erigir una piedra, ponerla en posición vertical, es un acto de reconocimiento simbólico: la piedra se convierte en una presencia y así comienza un diálogo." ["To erect a stone, to place it in a vertical position, is an act of symbolic recognition: the stone is converted into a presence and thus commences a dialogue."]

[John Berger. 2004, 245. El tamaño de una bolsa.

Buenos Aires: Taurus.]

\section{Introduction}

Current archeological views see material culture as the embodiment of relations between humans and their environment, and thus as a vehicle for memory and social identity. Taking this perspective, we aim to use a contextual study of the spatial and temporal distribution of Fishtail points (FTPs) to relate human actions and decisions to the colonization of landscapes in South America. This perspective goes beyond the analysis of the production and use of such tools, issues generally considered from technological, economic, and functional points of view. The temporal distribution of these points in South America $\left(11.6-9{ }^{14} \mathrm{C}\right.$ yr BP) allows us to infer that their production and use were linked to the slow tempo ${ }^{1}$ of the initial colonization of the continent.

Correspondence to: laura.miotti2@gmail.com
We aim to show that the geographical configuration of these artifacts is a marker of the way in which environmental information was circulated socially (Rockman 2003), and we use it to reconstruct the early relations between South Americans and their environment.

FTPs have an extensive research history in the Americas, and their academic interest is comparable only to that of Clovis points in North America. Following Frison (1990), we agree that this interest is related to their archeological association with extinct faunas and the earliest well-documented human presence in the continent. The first published data about an FTP finding were recorded in the work by Florentino Ameghino, who described a context in the Buenos Aires coastal locality of San Cayetano, highlighting a strange point that until that time had not been recorded (Ameghino 1915: 42, print 1, 130). Two decades later, Bird (1988) reported FTPs in the distant region of Magellan, in the deep strata of Fell's Cave. From then onward, many FTPs were recorded, widening our knowledge of their geographical and contextual variability. Isolated surface findings are numerous, but FTPs also appear in stratigraphic archeological contexts. They are frequently found in both camp and kill sites; however, they are scarce, and only in a few places have more than two specimens been found together (Figure 1, Table 1), for example 


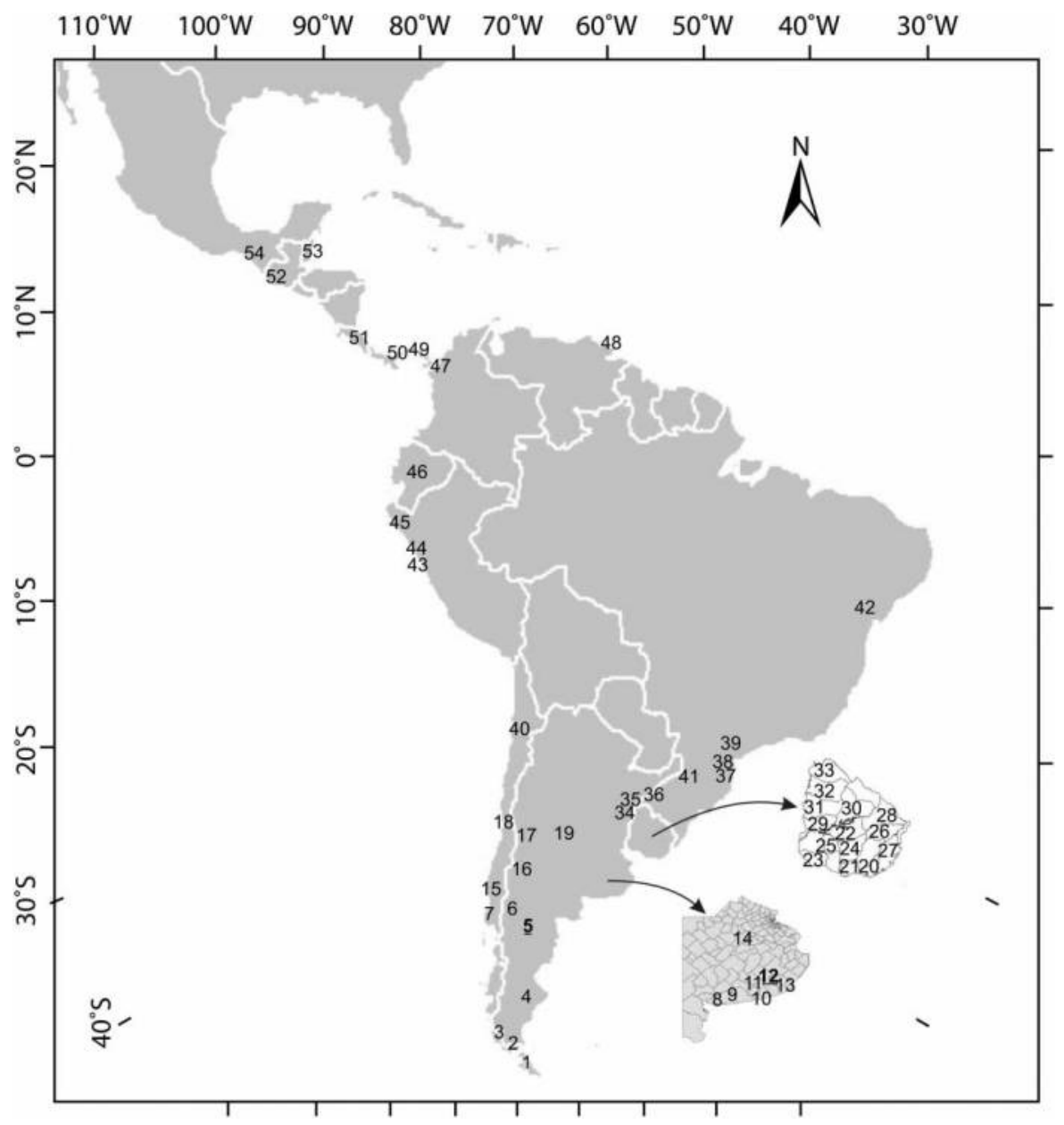

Figure 1 Map of South America showing places with FTPs.

24 in the Negro River basin of the Tacuarembó region, Uruguay (Nami 2007; Suárez 2011), and 21 from surface and stratified contexts at the El Inga site in Ecuador (Mayer-Oakes 1986).

In recent decades, though, with an increase in regional investigations of Pleistocene/Holocene sites, FTPs increasingly have been found in numerous contexts (Dillehay 2010; Flegenheimer 2003; Hermo and Terranova 2012; Laguens et al. 2007; Mazzanti 2003; Miotti and Terranova 2010; Miotti 1996; 2010a; Miotti et al. 2011; 2012; Nami 1987, 2007; Núñez et al. 1994, 2005; Suárez 2011) (for further details see Table 1). This work has added two more sites with abundant FTPs: Cerro El Sombrero (CoES) and Cerro Amigo Oeste (CoAW) (Flegenheimer et al. 2013; Hermo and Terranova 2012; Mazzia and Flegenheimer 2012; Miotti and Terranova 2010, 2011; Miotti et al. 2012; Weitzel 2010).

Thus, the picture that has emerged is one where FTPs are lightly scattered throughout much of the South American continent, but in a few localities, they are abundant. What does this distribution mean? The aim of this paper is to present the archeological markers of CoAW, in northern Patagonia, to compare its context, mainly with CoES, and to discuss how these first inhabited places inform us about the tempo and social practices leading to the initial colonization of South America.

\section{Cerro Amigo Oeste, Northern Patagonia}

The CoAW site is on the westernmost of two high mesas that are jointly referred to as Los Dos Amigos (LDA). The mesa is a volcanic butte shaped by later eolian action (IGM (1986), Hoja 4169-IV, Maquinchao, 1986). Erosion of the underlying tuff gave this butte its truncated cone shape, with a crown of more resistant basalts and slopes of volcanic tuff with an average slope around $12^{\circ}$. The mesa's summit lies about $125 \mathrm{~m}$ above the lagoon level. The mesa, together with the north bank of Las Vacas Lagoon and the adjacent plain, constitutes the archeological locality LDA. CoAW itself covers about $10,000 \mathrm{~m}^{2}$ (Figure 2). In November 2008, we found on the summit of CoAW the greatest FTP concentration; previously, we had recovered three FTPs on the plain surrounding it (Miotti 2010a; Miotti and Terranova 2010, 2011; Miotti et al. 2011).

The archeological and landscape features of LDA are so far only comparable with CoES in Tandilia Hills, in the Pampa region (Flegenheimer 2003). 
Table 1

Archeological FTP contexts and distribution in South America

\begin{tabular}{|c|c|c|c|c|c|}
\hline No. & $\begin{array}{l}\text { Name of site/ } \\
\text { locality }\end{array}$ & ${ }^{14} \mathrm{C}$ yr BP & Context & $\begin{array}{l}\text { Quantity of } \\
\text { FTPs }\end{array}$ & References \\
\hline 1 & Tres Arroyos 1 & $11,085-10,130$ & Stratigraphic & 3 & Massone $(2003,2004)$ \\
\hline \multirow[t]{3}{*}{2} & Pali Aike & 8639 & $\begin{array}{l}\text { Stratigraphic and } \\
\text { surface }\end{array}$ & 2 & Bird (1988), Nami (1999) \\
\hline & Fell & $11,000-10,720$ & Stratigraphic & 20 & Bird (1988) \\
\hline & Magallanes & $\mathrm{n} / \mathrm{d}$ & Surface & 1 & Bahamondes and Jackson (2006) \\
\hline \multirow[t]{2}{*}{3} & Cueva del medio & $11,120-10,310$ & Stratigraphic & 2 & Nami (1987) \\
\hline & Lago Sofía Cave 4 & $11,570-10,140$ & Stratigraphic & 1 & Prieto (1991) \\
\hline \multirow[t]{2}{*}{4} & Cerro Vanguardia & $\mathrm{n} / \mathrm{d}$ & Surface & 1 & Miotti et al. (1996) \\
\hline & Piedra Museo & $10,470-9,710$ & Stratigraphic & 2 & Miotti et al. (1999) \\
\hline \multirow[t]{4}{*}{5} & Tapera Isidoro & $\mathrm{n} / \mathrm{d}$ & Surface & 1 & Miotti (2010a) \\
\hline & LDA 5 & $n / d$ & Surface & 2 & Miotti et al. (2009) \\
\hline & Abra site & $n / d$ & Surface & 1 & Miotti et al. (2004) \\
\hline & CoAW & $n / d$ & Surface & 131 & Miotti et al. (2010a, 2010b) \\
\hline \multirow[t]{5}{*}{6} & Arroyo Corral 2 & 10,020 & Stratigraphic & 1 & Arias et al. (2010) \\
\hline & Trailal-Tué & $\mathrm{n} / \mathrm{d}$ & Surface & 1 & Nami (1992) \\
\hline & La Marcelina 1 & 1700 & Stratigraphic & 1 & Crivelli Montero (2010) \\
\hline & Piedra del Aguila & $\mathrm{n} / \mathrm{d}$ & Surface & 1 & Shobinger (1957) \\
\hline & Río Limay & $\mathrm{n} / \mathrm{d}$ & $\mathrm{n} / \mathrm{d}$ & 1 & Politis (1991) \\
\hline 7 & Temuco 1 & $n / d$ & Surface & 1 & Dillehay (1997) \\
\hline 8 & Río Sauce Chico & $n / d$ & Surface & 1 & Politis (1991) \\
\hline 9 & San Cayetano & $n / d$ & Surface & 2 & Ameghino (1915), Politis (1991) \\
\hline 10 & Bellamar 3 & $n / d$ & Surface & 1 & Bonomo (2005) \\
\hline 11 & Paso Otero 5 & $10,440-10,190$ & Stratigraphic & 2 & Martínez (2001), Holliday et al. (2003) \\
\hline \multirow[t]{4}{*}{12} & La Amalia 2 & 10,425 & Stratigraphic & 1 & Mazzanti (2003) \\
\hline & La China 1 & $10,804-10,520$ & Stratigraphic & 1 & $\begin{array}{l}\text { Flegenheimer (1980), Flegenheimer and } \\
\text { Zárate (1997) }\end{array}$ \\
\hline & La China 2 & $11,150-10,560$ & Stratigraphic & 1 & $\begin{array}{l}\text { Flegenheimer (1980), Flegenheimer and } \\
\text { Zárate (1997) }\end{array}$ \\
\hline & El Sombrero & $10.725-10,270$ & Stratigraphic/surface & $126^{*}$ & Flegenheimer $(2003,2004)$ \\
\hline \multirow[t]{2}{*}{13} & Los Pinos & $10,465-9,570$ & Stratigraphic & 1 & Mazzanti (2003) \\
\hline & Cueva Tixi & $10,375-10,045$ & Stratigraphic & 1 & (Mazzanti, personal communication) \\
\hline 14 & Lobos & $\mathrm{n} / \mathrm{d}$ & Surface & 1 & Politis (1991) \\
\hline 15 & Tagua Tagua 2 & $10,120-9,710$ & Stratigraphic & 3 & Nuñez et al. (1994) \\
\hline 16 & Ranquil Norte & $\mathrm{n} / \mathrm{d}$ & Surface & 1 & \\
\hline 17 & La Crucecita & $n / d$ & Surface & 1 & Garcia (2003) \\
\hline 18 & Valiente & $10,700-9,970$ & Stratigraphic/surface & 2 & Mendez et al. (2010) \\
\hline \multirow[t]{2}{*}{19} & ELS wtf & $\mathrm{n} / \mathrm{d}$ & Surface & 2 & Laguens et al. (2007) \\
\hline & Río Tercero & $n / d$ & $\mathrm{n} / \mathrm{d}$ & 1 & Politis (1991) \\
\hline 20 & Maldonado & $\mathrm{n} / \mathrm{d}$ & $\mathrm{n} / \mathrm{d}$ & 7 & Suárez (2011) \\
\hline 21 & Canelones & $\mathrm{n} / \mathrm{d}$ & $\mathrm{n} / \mathrm{d}$ & 3 & \\
\hline 22 & Rocha & $n / d$ & $\mathrm{n} / \mathrm{d}$ & 8 & \\
\hline 23 & Colonia & $n / d$ & $\mathrm{n} / \mathrm{d}$ & 2 & \\
\hline 24 & Florida & $n / d$ & $\mathrm{n} / \mathrm{d}$ & 2 & \\
\hline 25 & Flores & $n / d$ & $n / d$ & 2 & \\
\hline 26 & Treinta y tres & $n / d$ & $\mathrm{n} / \mathrm{d}$ & 1 & \\
\hline 27 & Durazno & $n / d$ & $n / d$ & 8 & \\
\hline 28 & Cerro Largo & $n / d$ & $n / d$ & 1 & \\
\hline 29 & Río Negro & $n / d$ & $n / d$ & 4 & \\
\hline 30 & Tacuarembó & $n / d$ & $n / d$ & 24 & \\
\hline 31 & Paysandú & $\mathrm{n} / \mathrm{d}$ & $\mathrm{n} / \mathrm{d}$ & 3 & \\
\hline 32 & Salto & $n / d$ & $\mathrm{n} / \mathrm{d}$ & 2 & \\
\hline 33 & Artigas & $n / d$ & $\mathrm{n} / \mathrm{d}$ & 7 & \\
\hline 34 & Santa Eloisa & $n / d$ & Surface/collection & 1 & Capeletti (2011) \\
\hline 35 & Santa Lucía & $n / d$ & Surface & 3 & Mujica (1995) \\
\hline 36 & RS-I-69 & $10,985-9,620$ & Stratigraphic & 1 & Miller (1987) \\
\hline 37 & Capivara & $\mathrm{n} / \mathrm{d}$ & Surface & 1 & Smith (2012) \\
\hline 38 & Santa Catarina & $n / d$ & Surface & 2 & Prous and Fogaça (1999) \\
\hline 39 & Paraná & $n / d$ & Surface & 1 & Prous and Fogaça (1999) \\
\hline 40 & Punta Negra & $10,470-9,180$ & Stratigraphic & 1 & Grosjean et al. (2005) \\
\hline 41 & Río Claro & $n / d$ & Collection & 5 & Beltrao (1974) \\
\hline 42 & Bahía & $n / d$ & $\mathrm{n} / \mathrm{d}$ & 1 & Nami (2011) \\
\hline 43 & Jequetepeque & $11,000-10,500$ & $\mathrm{n} / \mathrm{d}$ & 4 & Briceño (1999), Dillehay (2011) \\
\hline 44 & Valle de Moche & $\mathrm{n} / \mathrm{d}$ & $n / d$ & 1 & Ossa (1976) \\
\hline 45 & Piura & $n / d$ & $n / d$ & 1 & Chauchat and Zevallos Quiñones (1979) \\
\hline 46 & El Inga & 9330 & Stratigraphic/surface & 21 & Mayer-Oakes $(1966,1986)$ \\
\hline 47 & Bahía Gloria & $\mathrm{n} / \mathrm{d}$ & Surface & 1 & Cooke (1998) \\
\hline 48 & Isla Margarita & $\mathrm{n} / \mathrm{d}$ & $n / d$ & 1 & Nami (2011) \\
\hline 49 & Madden Lake & $n / d$ & Surface & 6 & Bird and Cooke (1977) \\
\hline 50 & Turrialba & $n / d$ & Surface & 1 & Snarskis (1979) \\
\hline
\end{tabular}


Table 1

Continued

\begin{tabular}{|c|c|c|c|c|c|}
\hline No. & $\begin{array}{c}\text { Name of site/ } \\
\text { locality }\end{array}$ & ${ }^{14} \mathrm{C}$ yr BP & Context & $\begin{array}{l}\text { Quantity of } \\
\text { FTPs }\end{array}$ & References \\
\hline 51 & Birlen & 4500 & Stratigraphic & 1 & Leon (2006) \\
\hline 52 & Tapiales & $n / d$ & $\mathrm{n} / \mathrm{d}$ & 1 & Gruhn and Bryan (1977) \\
\hline 53 & Belice & $\mathrm{n} / \mathrm{d}$ & $\mathrm{n} / \mathrm{d}$ & 1 & Nami (2011) \\
\hline 54 & Los Grifos & $9540-8930$ & Stratigraphic & 2 & Acosta Ochoa et al. (2010) \\
\hline
\end{tabular}

*90 FTP belong to Cerro El Sombrero Cima, 32 in the Noceda collection, 6 from Museo D (Arce collection), and 2 come from the stratigraphic deposit of Cerro El Sombrero Rockshelter 1.

The LDA locality lies on the Somuncurá Plateau, in northern Patagonia (Figure 3). This mountain range is at about 1000 masl and consists of extensive lava plateaus and volcanic structures (Masera 1998; Miotti et al. 2004, 2011). The plateau itself is star-shaped, and streams radiate outward from its center (Figure 4). It also has numerous bajos, resulting from wells and circular depressions, where at the bottom there are temporary pluvial lagoons and permanent lagoons fed by freshwater sources. Many of the volcanic structures such as the chimneys, laccoliths, cones, and buttes give this landscape a mountain physiography rather than a flat and monotonous plateau (Remesal et al. 2001). Springs are common and support vegetation. In arid and semiarid regions such as the Patagonian plateaus, water is a critical resource; its availability makes the difference between inhabited and transient places (Miotti 1998, 2006, 2008). Inhabited places are certainly of great significance for human settlement in the past. This fact is supported by both the recorded archeological evidence and the modern population of the plateau, which inhabits these same places, with an economy based on goat (Ovis capra) and sheep (Ovis aries) shepherding.
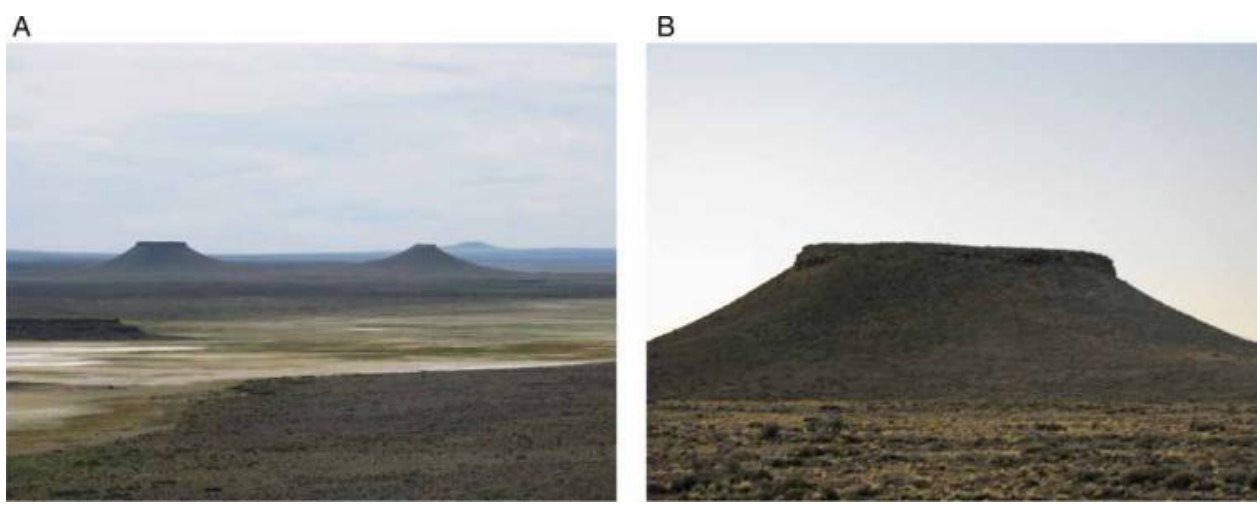

Figure 2 (A) View of Los Dos Amigos locality displaying the two buttes and Las Vacas Lagoon; (B) Cerro Amigo Oeste site (CoAW).

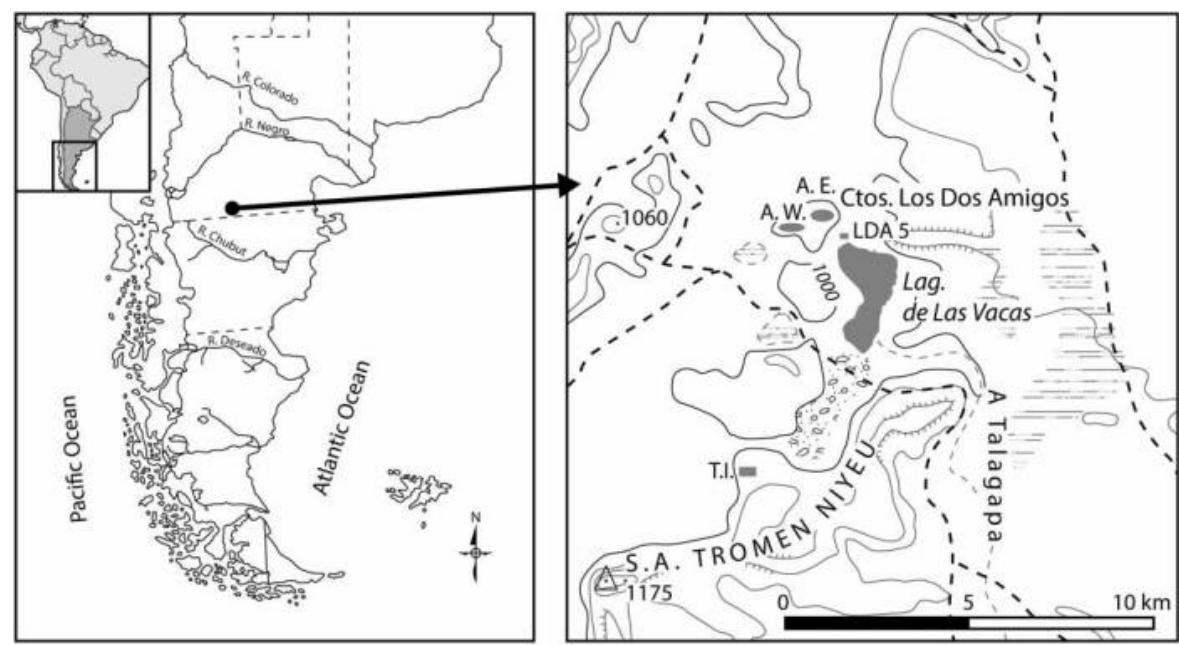

Figure 3 Topographic map of Somuncurá Plateau, displaying Los Dos Amigos locality (LDA). 


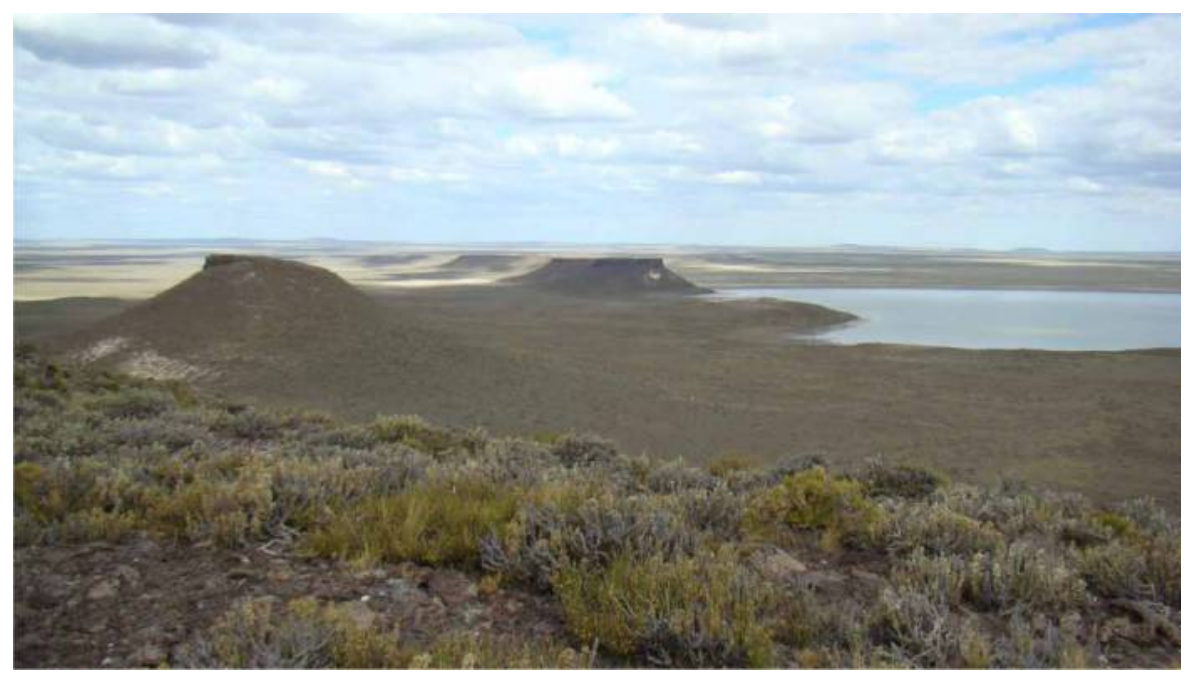

Figure 4 View from the top of Cerro Amigo Oeste.

\subsection{Archeological context}

As expressed in the introduction, few experts would doubt an interpretation of FTPs as weapons for the hunting of large land animals at the end of the Pleistocene. At CoAW, these points are found in surface contexts; therefore, at the moment, there are no radiometric dates to provide an exact age of the site. However, all the South American sites with FTPs in dateable contexts have been dated to the Pleistocene/Holocene transition (Table 1, Figure 5). The closest one is Arroyo Corral 2, which is located $250 \mathrm{~km}$ away, in the Neuquén Andes, at a similar latitude to that of CoAW. Arroyo Corral 2 is situated in a very different environment: it is a rockshelter in the steppe/forest ecotone (Arias et al. 2010). It is noteworthy that only one FTP specimen has been found at this site.
The archeological context of CoAW includes some 280 shaped lithic artifacts (SA), of which 131 correspond to FTPs. Most of them are broken at the stem and others at the blade (Figures 6, 7, Tables 3, 4).

Raw materials of the FTPs and other SAs are mainly of local origin, though some, as in the case of obsidian points, could have come from 40 to $100 \mathrm{~km}$ away (Miotti et al. 2012). In other cases, like siliceous rocks, the closest sources are $40 \mathrm{~km}$ south of the site (Hermo et al. 2013b; Miotti and Terranova 2011). Chalcedony is the prevailing raw material among the artifacts of CoAW (Table 2), and it is common at the LDA locality as well as almost all the sites of the Somuncurá Plateau (Terranova 2013). At the moment, the only primary quarry detected in the region (and partially studied) is that of Cerro Aneken, $15 \mathrm{~km}$ west of CoAW (Table 2).

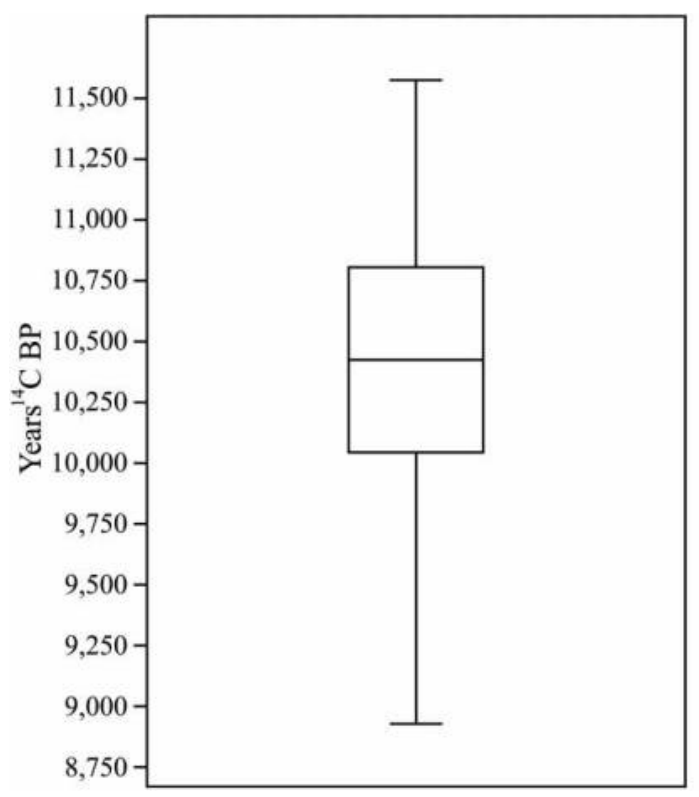

\begin{tabular}{|l|c|}
\hline Chronology & Years ${ }^{14} \mathrm{C} \mathrm{BP}$ \\
\hline Minimum & 8,930 \\
\hline Maximum & 11,570 \\
\hline Mean & 10,379 \\
\hline Median & 10,425 \\
\hline 25 percentile & 10,063 \\
\hline 75 percentile & 10,784 \\
\hline
\end{tabular}

Figure 5 Boxplot showing the temporal trend expressed in radiocarbon dates of South American archeological contexts with Fishtail points. 
Completeness AW

\section{COMPLETE}

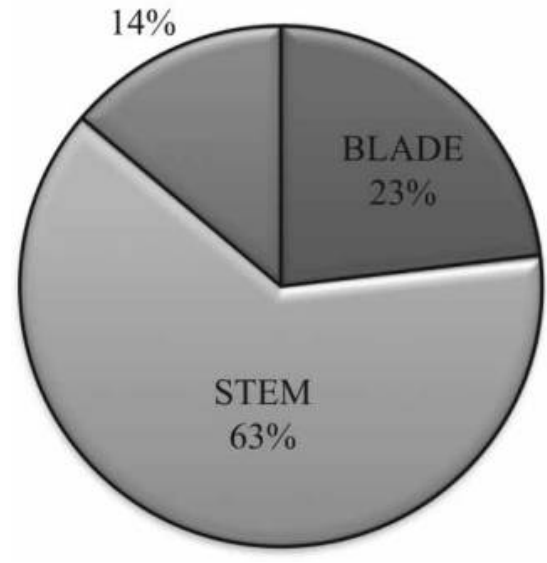

Figure 6 Graph shows per cent completeness of Fishtail points.

Other tools that occur with FTPs include discoidal stones, five of which are present on the summit of CoAW, four on basalt, and one on chalcedony (Figure 8) (mean diameter, $9 \mathrm{~cm}$; mean thickness, $4 \mathrm{~cm}$ ). The shaping of these artifacts was made by percussion, picking, smoothing, and polishing (Hermo et al. 2013a; Miotti and Terranova 2010, 2011). These pieces are technologically and morphologically similar to those found at CoES, Fell's Cave, Los Toldos, Hill de Los Burros, and Baño Nuevo, among others (Cardich et al. 1973; Flegenheimer et al. 2013; Jackson and Méndez 2007; Meneghin 2011; Terranova et al. 2010). Discoidal stones found elsewhere are fashioned from a variety of raw

Table 2

Raw materials represented among FTPs from Cerro Amigo Oeste

\begin{tabular}{lrc}
\hline Raw material & Frequency & Per cent \\
\hline Chalcedony & 88 & 67 \\
Silex & 26 & 20 \\
Obsidian & 9 & 7 \\
Quartz crystal & 5 & 4 \\
Petrified wood & 1 & 1 \\
Indeterminate & 1 & 1 \\
Total & 130 & \\
\hline
\end{tabular}

Table 3

Completeness and fragmentation of FTPs in archeological sites of the Somuncurá Plateau: CoAW and Tandilia Hill (CoES)

\begin{tabular}{lll}
\hline & \multicolumn{2}{c}{ Site } \\
\cline { 2 - 3 } Artifact & CoAW $(\boldsymbol{n}=\mathbf{1 3 0})$ & CoES Cima $(\boldsymbol{n}=\mathbf{7 2})^{\star}$ \\
\hline Blade fragment & $23.07 \%$ & $23.54 \%$ \\
Stem fragment & $63.07 \%$ & $61.76 \%$ \\
Complete & $13.84 \%$ & $14.7 \%$ \\
\hline
\end{tabular}

*The number for CoES Cima was taken from Weitzel (2010).
Table 4

Main comparison attributes between Cerro El Sombrero Cima and Cerro Amigo Oeste

\begin{tabular}{|c|c|c|}
\hline Attributes from sites & CoESC* & CoAW** \\
\hline $\begin{array}{l}\text { Elevation above sea } \\
\text { level }\end{array}$ & $428 m$ & $1125 \mathrm{~m}$ \\
\hline $\begin{array}{l}\text { Approximate } \\
\text { elevation above } \\
\text { plain }\end{array}$ & $200 \mathrm{~m}$ & $125 \mathrm{~m}$ \\
\hline $\begin{array}{l}\text { Approximate mesa- } \\
\text { top surface }\end{array}$ & $25,000 \mathrm{~m}^{2}$ & $12,000 \mathrm{~m}^{2}$ \\
\hline Maximum visibility & $40 \mathrm{~km}$ & $45 / 60 \mathrm{~km}$ \\
\hline Geomorphology & Butte & Butte \\
\hline Distance to water & $\begin{array}{l}0.5 \mathrm{~km} \text { to Ao. El } \\
\text { Verano }\end{array}$ & $\begin{array}{l}0.6 / 2.4 \mathrm{~km} \text { to } \\
\text { springs }\end{array}$ \\
\hline $\begin{array}{l}\text { Distance to most } \\
\text { frequent toolstone }\end{array}$ & $40 \mathrm{~km}$ & $15 \mathrm{~km}$ \\
\hline Number of tools & 1411 & 267 \\
\hline $\begin{array}{l}\text { Number of Fishtail } \\
\text { projectile points / } \\
\text { preforms }\end{array}$ & 90 & 116 \\
\hline $\begin{array}{l}\text { Fragmented Fishtail } \\
\text { projectile points }\end{array}$ & $85 \%$ & $87 \%$ \\
\hline Flakes & 9640 & $\sim 2200$ \\
\hline Cores & 4 & 3 \\
\hline Small spheres & 3 & 1 \\
\hline Discoidal stones & 2 & 4 \\
\hline Others & $\begin{array}{l}6 \text { unidentified ground } \\
\text { fragments, ocher, } \\
\text { hammerstone, and } \\
\text { abrasives }\end{array}$ & 1 hammerstone \\
\hline
\end{tabular}

*Information collected from Área Arqueología y Antropologia, Municipalidad de Necochea (Mazzia and Flegenheimer 2012; Mazzia 2011; Weitzel 2010, 2012).

**Information from Hermo and Terranova (2012), Miotti and Terranova $(2010,2011)$.

materials, depending on local availability (Hermo et al. 2013b). A sphere of polished ocher, $2 \mathrm{~cm}$ in diameter, was also recovered from CoAW (Figure 8). This type of artifact has only been found elsewhere at CoES (Mazzia and Flegenheimer 2012).

The shaped tools from CoAW entered the site fully manufactured or as bifaces. There are spatially limited concentrations of small bifacial thinning and resharpening flakes, suggesting objects entering the site already manufactured. The number of broken items is high, while there are fewer resharpened and recycled items (Tables 2, 4 and Figure 9). These attributes suggest that points, once broken, possibly in the surrounding hunting field, were transported to the summit of the hill and there extracted from the shafts, mended, recycled, or discarded. However, we have to take into account that these instruments, even broken, continued to be of significance to the ancient hunters and that their discard on the summit may constitute another stage of their use-lives. From then on, the artifacts may have had another purpose. In this sense, unhafting and depositing of broken points on the mesa top, now useless as weapon heads, could represent offerings to the place itself. If true, this would establish the relation between human 


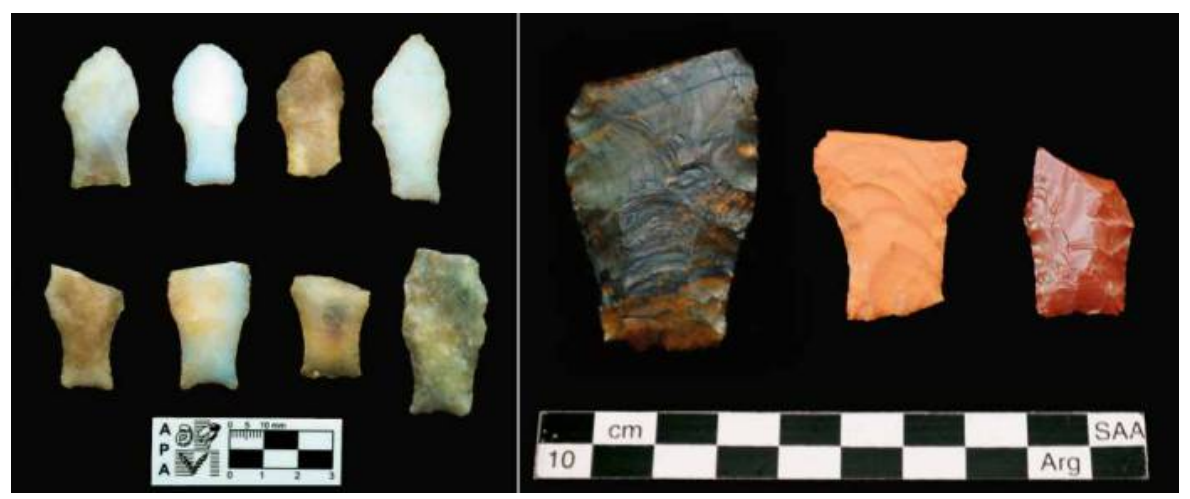

Figure 7 Fishtail points from Cerro Amigo Oeste.

beings and the symbolic spheres of the landscape in which some places, such as CoAW, would eventually contain large numbers of complete or broken artifacts, which, technologically, display a high degree of conservation. Let us remember that this mesa, together with the butte of Amigo Este (CoAE), is grouped in current cartography into LDA (Figure 2). Both were considered by Pampa-Patagonian hunter-gatherers who passed through Somuncurá in the eighteenth and nineteenth centuries as the gateways to the sacred complex of guanaco hunting. In Tehuelche, this place was called Yamnagoo (Claraz 1988; Moreno n.d.; Miotti et al. 2004); however, in the twentieth century, this name disappeared from the regional toponymy, and like all Tehuelche terms was replaced by a Mapuche name at the beginning of the nineteenth century, and therefore from that moment was unknown by the region's inhabitants. Today the area is known as Tromen Niyeu, a Mapuche term that means place of fallen reeds (Casamiquela, in Claraz 1988).

We cannot establish an analogy between the significance given to these mesas by the hunters of the nineteenth-century buttes and the meaning that the first late Pleistocene settlers of the area may have given to it. But, in fact, the summit of CoAW is covered by a great number of special objects of material culture such as FTPs, most of them broken, and discoidal stones, which together represent an important archeological sign of use of this place during the Pleistocene/ Holocene transition.
The presence of complete and broken preforms, together with FTPs, allows us to infer the transport to the mesa summit of basic forms and disposal of them primarily during the re-equipment of lithic points surely accompanying pre-hunt activities (fauna sighting, point shaping, recycling, and discard of broken FTPs).

Within a model of space use with a strategy of "store cache" or "gear cache" (Binford 1978, 1993; Frison and Bradley 1999), CoAW meets the expectations of an area of lithic tool re-equipment. However, the presence of complete FTPs there is not part of this designation. How, then, can we explain the complete points? Their presence likely does not relate to problems of raw-material economy, but to a concept more linked to "ritual deposit" and/or "ritual trash" (Boivin and Owoc 2004; Lassen 2005; Messineo et al. 2005; Vilca 2011; Walker 1995). In this respect, the site served as a place for specific practices of offerings and rituals. The setting of CoAW, together with several ethnographic and ethnoarcheological examples, allows us to infer that the materials represented in the site correspond to a special workshop, the likely function of which was the replacement and/ or re-conditioning of FTPs. This does not rule out, however, the idea that the broken points and other special materials (i.e., discoidal stones and ocher spheres) were taken there intentionally. In this sense, CoAW could have witnessed a variety of activities, including re-equipment, fauna and human-being

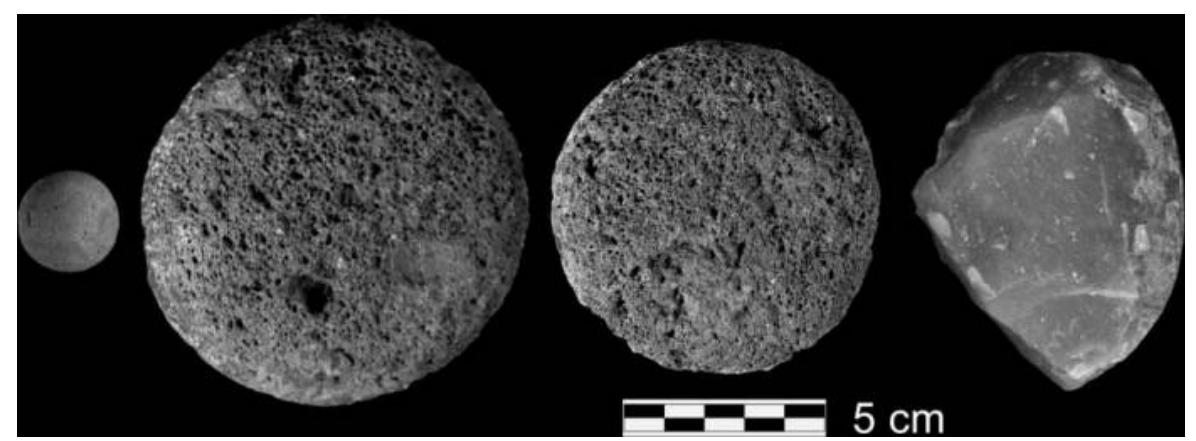

Figure 8 Discoidal stones and ocher sphere from Cerro Amigo Oeste. 
sightings, and possibly the performance of rituals that entailed offerings (Boivin and Owoc 2004; Taçon 1991; Torrence 2005, 2011; Walker 1995).

\subsection{Los Dos Amigos in nineteenth-century chronicles}

In nineteenth-century chronicles, several naturalists such as Claraz [(1864) 1988] and Moreno [(1883) n.d.] described the LDA mesas that form the huge arcades of the great field of communal hunting of Tehuelche Pampa people. As noted above, its name was Yamnagoo, which in the Tehuelche language means "run and drink," perhaps synonymous with "hunter-gatherers" paradise." LDA was a spot where water was abundant, and where herds of fat guanacos congregated. Both chronicles add that the site was located at an important Indian crossroads between the Atlantic and the Andes.

Claraz (1988) described in detail the ways huntergatherers ambushed and caught guanacos. In the LDA area, in 2008, we identified several potential monuments of rocks to ancient gods such as Yamhoc, the lady of the field and the animals, and the Yamnagoo arcades (Miotti et al. 2004, Miotti 2008). In Claraz's words (1988), "Dos cerros, verdaderos bonetes [...] Finalmente, junto a esos dos cerros que quedaban a mano derecha, el suelo se eleva ligeramente y se divisaba el gran Bajo de Yamnago." In the same way, it was expressed by Moreno (n.d.): " $A$ la salida de ese casi laberinto encontramos los pórticos que dan entrada al llano de Yamnagoó, tan celebrado por los indigenas [...] Cruzamos esas enormes puertas (Cerritos los Dos Amigos) y penetramos en el famoso valle, primero estéril, luego fertilísimo [...]."

What could be the relationship between the same sacred place of hunting of the nineteenth century and the archeological site that we suppose dates to the Pleistocene/early Holocene transition?

A possibility is that the hill was given meaning on its summit by the archeological hunting-related objectsthe projectile points - deposited there. Moving the points to the summit would not be necessary for discarding those pieces. The broken points could have been abandoned in the surrounding plain where they were most likely used and damaged. However, they were moved $125 \mathrm{~m}$ upward and discarded or left. The climb and the tasks on the summit may have been repeated, maybe as a routine practice (sensu Laguens 2009), because the hundreds of lithic materials found are not interpreted as a synchronic deposit, but as the result of multiple events of depositing, suggesting an intentionality in discarding the fragmented pieces in the same place. Therefore, the context of CoAW allows us to infer a complete knowledge of the plateau environment on the part of the first hunters of the area and the materialization of practices that may mark a socially known environment and significant place (sensu Rockman 2003; Vilca 2011; Walker 1995).

Materials corresponding to the middle or late Holocene are not recorded on the mesa. However, we have recorded settlements of the pre- and postHispanic late Holocene on the surrounding plain (Miotti et al. 2004, 2009) and in the chroniclers' accounts, as mentioned above.

Can we then think that the mesa, from the beginning of human settlement in the area, was a place of re-equipment, sighting, and ritual? All the archeological and ethnographic evidence suggests that it was, despite the fact that it developed other practical functions such as a ceremonial site (Martínez 2006; Torrence 2005, 2011). We suggest the idea of continuity in the site's meaning during the Holocene, even though the site lacks Holocene artifacts because of the ethnographic account noted above.

\section{Comparison of Cerro Amigo Oeste and Cerro El Sombrero}

Both CoAW and CoES are located on buttes and have excellent views of the surrounding landscapes, in both cases with wide panoramas (Criado Boado 1993). This setting would have allowed hunters to track the movements of game, as well as those of people. The data detailed above, following the concepts of a relational archeology of peopling (Laguens 2009; Latour 1996; Law 1992; Meltzer 2003; Rockman 2003), allow us to consider them, in the frame of the archeology of colonization, as true places of control of the landscape and movements of human beings and animals (Figure 2). Their origins and local landscapes are variable, but both represent milestones or very conspicuous locations in both landscapes, natural signs in the roads of new territories, in the sense of Rockman (2003) and Meltzer (2003). CoES lies on a crystalline outcrop of Tandilia igneous bedrock. It is the highest elevation of the Tandilia Hills and it is only a few meters from a stream that flows through the surrounding plain. These sites are suited for sighting game, and thus were strategic points for hunting; on their summits, projectile points were resharpened and projectiles re-equipped (Flegenheimer 2003, 2004; Mazzia and Flegenheimer 2012; Hermo and Terranova 2012; Miotti 2010a, 2010b; Miotti and Terranova 2010, 2011; Miotti et al. 2009, 2011).

It is noteworthy that both sites are $900 \mathrm{~km}$ apart, separated by two important rivers of the Atlantic watershed, the Negro and the Colorado, as well as the Ventania chain of hills (Figure 1). CoAW lies on the arid volcanic plateau of Somuncura, in northern Patagonia, while CoES is in the field of southern hills of the Buenos Aires Humid Pampa sub-region. 


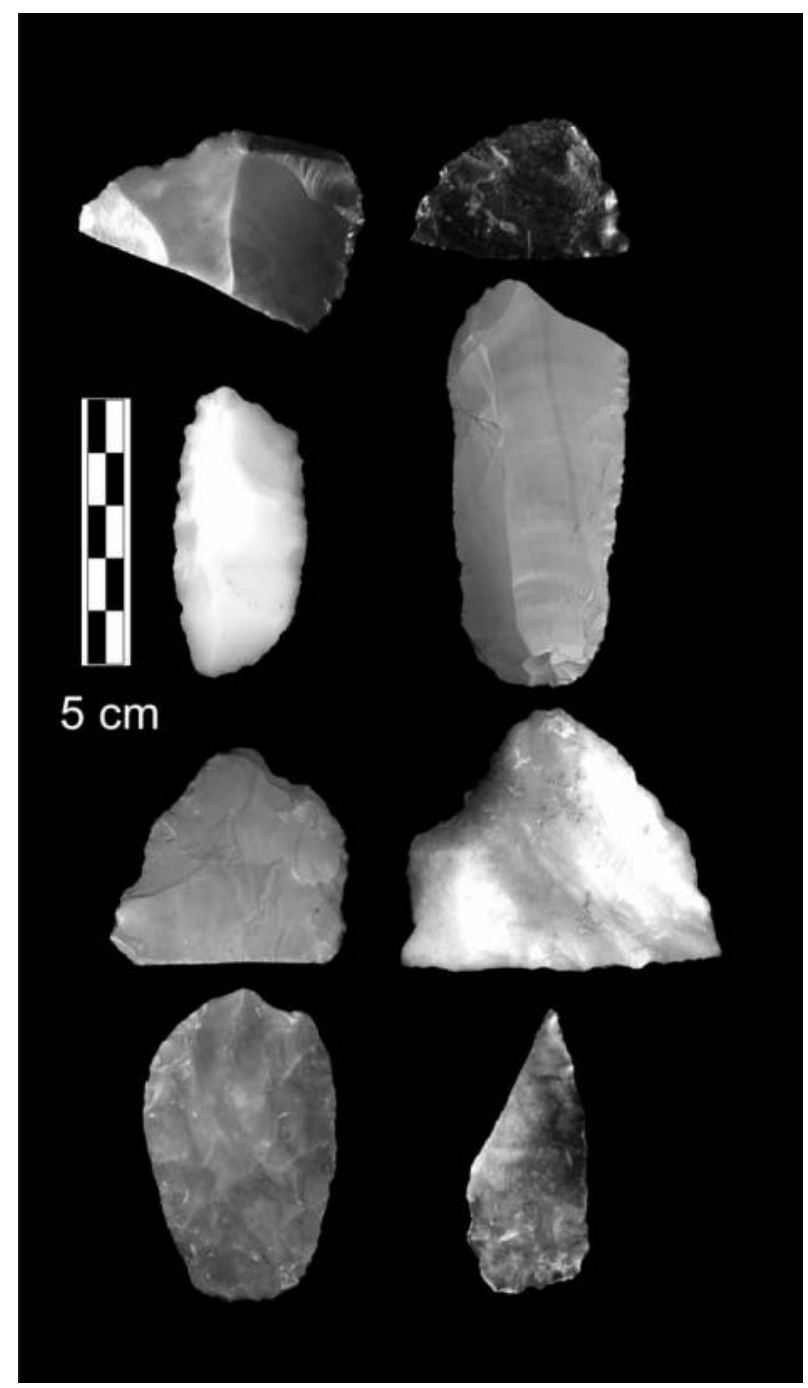

Figure 9 Bifaces and broken and recycled pieces from Cerro Amigo Oeste.

The archeological sites on their summits share many attributes, which could reveal a behavioral pattern of the societies that colonized the Southern Cone and that produced and used FTPs. The lithic debris at both sites suggests the manufacture of FTPs or other artifacts, and both contain large numbers of points and point fragments (Miotti and Terranova 2011). The point fractures are also similar (Tables 3,4) and indicate that broken pieces entered both sites as fragments. Both contain low proportions of FTPs manufactured on exotic toolstone. Their presence in both sites seems to be a common characteristic, also observed in other places of South America, such as in the kill/butchery site of Tagua Tagua (Flegenheimer et al. 2003; Miotti et al. 2012; Núñez Atencio et al. 1994). In Table 1, the frequencies of FTPs are detailed for the various sites shown in Figure 1.

The discoidal stones found at both sites (Table 4) and associated with FTPs are not found frequently in other early South American sites (Bird 1988;
Cardich et al. 1973; Flegenheimer 1980, 2004; Hermo et al. 2013b; Meneghin 2011). Although their functional interpretation is unknown, some researchers suggest they could be artifacts for vegetable grinding (Mazzia and Flegenheimer 2012), while others consider them to have had ritual uses (Jackson and Méndez 2007).

The abundance of tools already finished, such as FTPs, unifacial side scrapers, discoidal stones, and preforms, as well as pieces produced on long-distance rocks, could indicate some kind of regional pattern of circulation of human information. The similarity in both archeological sites of CoAW and CoES may suggest a similar pattern, and, in this sense, they could mark a higher signal of heterogeneous distribution of FTPs in the Southern Cone (see the functionality discussion in Flegenheimer et al. 2003; Nami 2007; Politis 1998; Suárez 2011). These artifacts have a technological similarity that spans the continent (see Figure 1), but with a limited temporal range (Figure 5), that of the initial colonization of the continent. This interpretation corresponds to the argued expectation of the structure and circulation of lithic raw materials in contexts of colonization of alreadyexplored landscapes, in the sense of Meltzer (2003) and others (e.g., Flegenheimer et al. 2003; Franco 2002; Miotti et al. 2009, 2012).

In both CoAW and CoES, the technological contexts coincide with the earliest moments of the hunting-gathering settlement and suggest re-equipment localities. But, in addition, both could mark identifiable paths during initial colonization of both regions. The archeological materiality of both contexts created landmarks for the hunters, who may have used the summits not only for catching sight of prey but also for communicating (and controlling) the mobility of human groups who passed through the respective hunting territories.

In the specific case of CoAW, the features of the surroundings are shared with those of arid-zone sites, such as Atacama, Punta Negra, Tuina 5, and Tambillo in Chile (Grosjean et al. 2005; Núñez Atencio et al. 2005) or Piedra Museo in southern Patagonia (Miotti 1996). These are often placed on the edge of old paleo-lakes that nowadays are salt lakes or shallow temporary lagoons. These features were interpreted in the same way as the Paleoindian sites of the Great Plains of North America, as ecoshelters, microenvironments with effective humidity higher than that of the surrounding arid environments (Frison and Todd 1987; Goebel et al. 2011; Miotti 1995; Miotti et al. 2008; Núñez et al. 1994; Willig 1991). In these landscapes, the existing bodies of water during the Pleistocene/Holocene transition served as refuges for human beings and animals. This concept involves continental aquatic 
environments (Erlandson 2001), which were extremely important in the settlement process during the Pleistocene/Holocene transition, when global environmental conditions were colder and drier (e.g., Hoganson and Ashworth 1993; Rabassa 2008). In all of these closed basins, two concomitant factors are observed: one is the repeated use of different regions by exploring and inhabiting settlers (inclusive places, sensu Gamble (1993)); the other is the dating of settlement to the late Pleistocene, by the presence of FTPs in the South American sites.

Is there a symbolic similarity of both places in the extensive Pampa and Patagonia territory? Our answer is affirmative because both places have similar and yet exceptional characteristics within the known archeological record of South American peopling. CoAW and CoES, however, were places of tool re-equipment of the first hunter-gatherers. Regarding all the contexts with FTPs in South America, these sites support the idea that, in addition, they could have been places for ritual practices and route control, which would have conferred upon them the quality of being nodes of social information within networks (Whallon 2006) of the first settlers that occupied both regions. The concept of node is understood as the place of social aggregation and transmission of environmental information, and it is widely used in the archeology of colonization (e.g., Flegenheimer 2003; Gamble 1993; Ingold 1986; Law 1992; Meltzer 2003; Miotti 2003, 2010b; Miotti and Terranova 2011; Miotti et al. 2012; Rockman 2003; Torrence 2005, 2011). Both Argentine sites also indicate a deliberate choice as key signals of routes between places (Meltzer 2003; Rockman 2003). The attribute of signal, in Rockman's sense, would be archeologically supported by the presence of abundant broken artifacts intentionally deposited on both summits, in order to signify the two places.

\section{Other sites with FTPs in South America}

As can be seen in Table 1 and Figure 1, FTPs are widely distributed in Latin America. Regarding the temporal range of the FTPs, reliable radiocarbon dates come from only 17 sites (Table 1), demonstrating the age of FTPs to be at the Pleistocene/Holocene transition. This period represents about 2000 years (Figure 5). Human groups would not have been moving any longer through a terra incognita, because they would have already acquired an environmental knowledge, socially transmitted, at least, by three generations (Rockman 2003). The people had not just arrived; the archeological evidence of the variety of raw materials used for the elaboration of FTPs indicates that they carefully chose toolstone (Table 5). This implies that other environmental resources also would have been widely known. That is to say, the chronological evidence, together with the great diversity of places where these points appear on the surface, allows inferring a high knowledge of most of the continent. Places were marked by the presence of artifacts elaborated with the same technological conception.

FTPs in South America are generally found in low numbers, with a prevalence of isolated findings and low concentrations $(<5)$ in sites (Figure 1 and Table 1). In this regard, CoAW and CoES stand out, as each contains more than 100 FTPs.

Distances between the sites where FTPs occur, however, are quite great (Figure 1). To what can we attribute this geographical configuration? A possible answer is that either CoAW or CoES was a node of social communication for the groups producing FTPs. And, even though in the region of the Negro River, Uruguay, FTP findings are isolated, they correspond to a limited area that could be similar to the two mesas discussed above (Flegenheimer et al. 2013). However, archeological research along the Negro River needs to continue to explore this possibility.

\section{Discussion}

In very few studies, FTPs have been related to sociological and symbolic spheres, as elements of communication and interchange of goods, which could have given identity and power to the humans settling the continent (Flegenheimer 2004; Flegenheimer and Bayón 1999; Miotti 1995, 2003, 2010a, 2010b; Nami 2009; Politis 1998; Storck 1991; Weitzel 2010). The spatial and temporal distribution of FTPs is interesting not only because they date to a narrow time period, about $11,000-9,000{ }^{14} \mathrm{C}$ yr BP (Table 1, Figure 5), but also because from their conception as artifacts exceeding simple functionality, they allow us to think about their implication for social networks of communication and interchange. This suggests that around $11,000{ }^{14} \mathrm{C}$ yr BP "scouting" groups could already interpret the unfamiliar environments of inhabited landscapes. Therefore, this presupposes a social-environmental dialog with a symbolic complexity of these societies, greater than the one imagined so far. It is worth highlighting that in some special locations some FTPs have appeared as miniatures (Flegenheimer 2004), the efficiency of which for hunting mega and large mammals is difficult to imagine. The presence of these objects in sites of the late Pleistocene has been interpreted to represent children's playful and/or adult-imitative activities (Flegenheimer 2004; Politis 1998; Storck 1991). This argument allows us to infer the active role that children could have played at CoAW and CoES, and counters conventional interpretations of these items as strictly hunting weapons. Obviously, FTPs served as objects with sociological and symbolic value, adding to their technological and practical value. In other words, 
these points likely had more meaning than we conventionally ascribe to them.

At CoAW, some FTP specimens have rounded blades resulting from resharpening and/or recycling, so that their distal angles would have been deficient to penetrate thick furs of mega and large mammals (Hermo and Terranova 2012; Suárez 2011); however, their location on the summit of the hill-together with numerous points, preforms, broken bifaces, and other exceptional objects such as discoidal stones and the sphere of polished ocher-supports the idea that their discard or loss on the summit was not only part of the routine of resharpening and re-equipping, but also part of ritual specialists' activities (Torrence 2011), for example landmarking along traveled routes, being deposited upon the mesa as symbolic offerings to game (Miotti and Terranova 2011; Miotti et al. 2012).

Thus, the FTPs and discoidal stones of CoAW could be items of social and symbolic communication like the female figurines (Venus) of the Upper Paleolithic of Eurasia (Gamble 1993; Grigor'ev 1993; Soffer and Praslov 1993), or like the Clovis caches of North America (e.g., Frison and Bradley 1999; Lassen 2005).

To Soffer and Gamble (1990) the spatial-temporal distribution of Venuses could have been due to the need to produce great numbers of items of social communication at certain places. Their circulation through the Old World could have been a means of social communication among geographically isolated human populations in a hostile environment. Based on the mapping of concentrations and dispersions of female figurines and other ritual objects representing sanctuary, Soffer and Gamble (1990) infer places of production of these objects and the maximum mobility reached by human beings into the Arctic. This model of social communication across long distances, from the abundant production of sanctuary objects and their transport to populations far from producers' centers implies social communication of human beings during one of the most inhospitable moments of the last glacial maximum $\left(18,000{ }^{14} \mathrm{C} \mathrm{yr} \mathrm{BP}\right)$. This model of compulsive production in moments of environmental stress receives the name of "Arctic Hysteria" (Gamble and Soffer 1990). The Venuses, beyond the trite interpretation as fertility fetishes, would have been transmitters of identities and buffers or modifiers of the uncertainties that human beings may have felt in places of geographical isolation.

Another similar example is found in the distribution of Clovis points in North America, and now we can add the example of the FTPs of South America. In this case, we find, as in the Old World, a heterogeneous geographic distribution and a limited temporal distribution, $11,300-12,900{ }^{14} \mathrm{C}$ yr BP. We might consider the ideological aspects of these artifacts. Both appeared during times of environmental stress, the last glacial maximum in the case of the Venus figurines, and colonization of unfamiliar territories in the case of Clovis. In the Old World, the presence of sacred objects (Soffer and Praslov 1993) in low quantities in the furthest of places, such as isolated high latitudes, compared to high concentrations in less geographically isolated production places, would represent the human interest of maintaining social communication and identity with places of the most difficult accessibility. Clovis might be a similar case, with its caches like Anzick and Fenn (Frison and Bradley 1999). In other caches, like Crowfield, more than $4.5 \mathrm{~kg}$ of chert artifacts were brought from $100 \mathrm{~km}$ or farther and then destroyed (Ellis 2009; Lassen 2005). In the Caradoc cache, Bayport chert was transported $175 \mathrm{~km}$ and then deliberately destroyed (Ellis 2009). In these cases, a large part of the material sacrificed were objects with long uselives, such as preforms and base forms of Clovis points. To Ellis (2009) this "waste" of raw material in concrete spots on the landscape shows that these caches were offerings in some kind of ritual. Historically, on a world scale, sacred rituals often involve or implicate the offering of material objects; these connect or rupture relations between different domains of the human existence - cosmological, religious (see, for example, Boivin and Owoc 2004; Lassen 2005; Saunders 2004; Taçón 1991; Torrence 2005, 2011).

These examples suggest that an interpretation of the spatial-temporal distribution of FTPs in South America may fit a larger pattern of the archeology of the late Pleistocene. CoAW and CoES could have been important nodes, not only as centers of production but also as nodes of social aggregation accompanied by ritual activity. These practices are considered as a metaphoric dialog between humans and landscape. Therefore, these places were already widely known by about $10,500{ }^{14} \mathrm{C}$ yr BP, a fact that allows us to infer that these routine practices, in places almost $1000 \mathrm{~km}$ apart, could have facilitated the rapid colonization tempo between the groups of La Pampa and Patagonia.

The important function in communication that these places may have had would have reduced risks of populations arriving into unknown environments, and at the same time would have strengthened the identity bonds of the original, possibly thinly spread dispersing population. Moreover, the circumscribed deposit of numerous artifacts may indicate the way in which humans were interpreting or dialoging with landscapes, signifying, naming, and taking possession of these places. In some ways, the redundancy of visits to CoAW and CoES also tells us the users of FTPs had wide knowledge of the broad geographical spaces and 
their resources over a 2000-year period (i.e., information on social scale, sensu Rockman 2003). In short, we can consider that the distribution of these objects in the regional landscape may have helped to increase the tempo of environmental knowledge, accelerating the colonization process.

\section{Conclusion}

The evidence presented in this work allows us to address questions concerning the means and tempos between the arrival of the first human groups in South America and the transformations of the nonfamiliar landscapes into socially inhabited, familiar ones. We infer that between 11,000 and $9,000{ }^{14} \mathrm{C}$ yr $\mathrm{BP}$, the Somuncura Plateau was a familiar landscape for the hunter-gatherers that were colonizing Pampa and Patagonia. In this sense, it appears that by at least $11,000{ }^{14} \mathrm{C}$ yr BP the "scouts" (or explorers) had already fulfilled their task and had a wide knowledge of where to settle and how to travel through the landscape. The information presented here also supports the idea, drafted in other South American studies, that existing social networks of environmental knowledge may have played a role in the colonization of South America. The materialization of those networks in the archeological record may be manifested in the particular spatial distribution of certain objects such as FTPs (Flegenheimer et al. 2003; Miotti 1995, 2003; Miotti and Terranova 2011). The establishment of social networks with nodes where routes, people, objects, and environmental information may have crossed could have been a strategy favoring slow-tempo scouting, accelerating human expansion, and the colonization tempo of different regions. In this context, CoAW appears to be an excellent candidate in the landscape of the Patagonian plateaus for having fulfilled, in principle, the role of a natural reference for the scouting of routes and nodes within a social network. The hill, in terms of the model of local, regional, and social learning of the environment (Rockman 2003) could have been a natural landmark and reference for the orientation of routes traveled by settlers. Beyond its function as a place for re-equipping hunters' tool kits, we should add to the significance of CoAW its meaning as a place for ceremonies, including offerings of special materials such as FTPs on its summit, possibly broken in the surrounding hunting field. This deliberate practice of taking the points to the summit and leaving them there may have had a similar meaning in the CoES site in the Pampa region. Both contexts, with many contextual and environmental similarities, as shown throughout this work, could have served as nodes consolidating the network of human environmental and social communication during the first moments of the peopling of the Southern Cone of
South America. This is potentially supported by the distribution of special cultural goods, the FTPs.

The high percentages of broken FTPs in both CoAW and CoES, however, conform with what has been expressed for ritual sites of North America, as presented here through the works by Lassen (2005) and Ellis (2009). Such special deposits would mark the human attitude of keeping some objects beyond their merely functional use-lives as weapons. This idea is reinforced by the presence of complete points and other special objects such as the discoidal stones and polished spheres.

In addition, historic chronicles indicate that in postcontact times, LDA was considered the gateway to a sacred hunting field (Yamnagoo) by Tehuelche Patagonian hunters. However, from archeology, there are no records of use of this hill or its summit. There is, indeed, archeological evidence of hunting activities and camp sites in the surrounding plain, but without a written document, the material record of these summits may indicate that they were used in a manner different from that described in the historic records.

The archeological sign of when and how human beings inhabited a place for the first time can be discerned when we consider that natural and cultural scenarios are interwoven into a network of dynamic relations. These dynamics are manifested in the socially shared knowledge at short and long distances of the circulation of people and objects. But there is also a circulation of accounts of places, concepts and styles, giving rise to social networks as another tool for diminishing the risk associated with the exploration of an unknown place. It is suggested that CoAW was an important node in a network of social relations through long distances in the Pleistocene/Holocene transition in South America. The concepts presented in this article may allow us to go further in this difficult issue and explore the archeological signals that will permit us to consider social networks and communication nodes at different geographical and temporal scales (Tolan Smith 1998; Whallon 2006).

\section{Acknowledgements}

We thank Ted Goebel for inviting us to contribute to this effort. We also thank him, Kelly Graf, Nora Flegenheimer, Darío Hermo, Rocío Blanco, and Laura Marchionni for their comments on this manuscript, and Bruno Pianzola for photos. A previous version was presented at the $\mathrm{V}$ Conference on First Americans in Argentina, 2010. We thank CONICET and ANPCyT for their financial support. We are very grateful to Bob Kelly, Ruth Gruhn, and an anonymous reviewer who made valuable comments for rethinking our original ideas. However, we alone are responsible for any errors. 


\section{Note}

1 Tempo is the unit used for measuring the auditory expressions of some musical segment. Usually we refer to tempo when talking of transitions of sound spaces, like when counting by ones until reaching 10 . Lento, andante, etc. In that sense, and according to Webb (2010), the peopling of America may have had a fast tempo. On the contrary, Meltzer (2003) considers that that tempo may have been slow.

\section{References}

Acosta Ochoa, G., P. Pérez Martínez, I. Rivera González, A. Jiménez Serrano, and X. Ulloa Nontemayor. 2010. "Reevaluando Los Grifos, un abrigo con puntas acanaladas del Holoceno temprano en México." In Libro de Resúmenes "El poblamiento temprano de América: a un siglo del debate Ameghino-Hrdlicka", edited by D. Hermo, and R. Blanco, 153. La Plata, Argentina.

Ameghino, F. 1915 (1880) La Antigüedad del Hombre en el Plata. Obras Completas y correspondencia científica de Florentino Ameghino, Vol. 3. La Plata: Dirigida por Torcelli, A.

Arias, P., A. Hajduk, A. Armendariz, A. Albornoz, A. Chauvin, M. Cueto, S. Goye, M. Lezcano, V. Fernández, P. Fernández Sanchez, E. Palacio, J. Tapia, and L. Teira 2010. Un nuevo núcleo de poblamiento temprano en el norte de la Patagonia: avance al estudio de los sitios del valle de Arroyo Corral (Neuquén, Argentina). Libro de resúmenes del V Simposio Internacional "El poblamiento Temprano de América: a un siglo del debate Ameghino-Hrdlicka”. La Plata, Argentina.

Bahamondes, F., and D. Jackson. 2006. "Hallazgo de una punta 'Cola De Pescado' en Magallanes, Chile." Magallania 34(2): $115-118$.

Beltrao, M. C. 1974. "Datacoes arqueológicas mais antigas doBrasil." Annais do Academia Brasilera de Ciencias 46(2): 211-251.

Binford, L. R. 1978. "Dimensional analysis of behavior and site structure: Learning from an Eskimo hunting stand." American Antiquity 43: 330-361.

Binford, L. R. 1993. "Bones for stone: Considerations of analogues for features found on the central Russian Plain." In From Kostenki to Clovis: Upper Paleolithic-Paleo-Indian Adaptations, edited by O. Soffer and N. Praslov, 101-123. New York: Plenum Press.

Bird, J. 1988. Viajes y arqueología en Chile austral. Puntas Arenas, Chile: Ediciones de la Universidad de Magallanes.

Bird, J., and R. Cooke 1977. Los artefactos más antiguos de Panamá. Panamá: Revista Nacional de Cultura 6.

Boivin, N., and M. A. Owoc. 2004. Soils, Stones and Symbols: Cultural Perceptions of the Mineral World. London: UCL Press.

Bonomo, M. 2005. Costeando las llanura: Arqueología del litoral marítimo pampeano. Buenos Aires: Sociedad Argentina de Antropología.

Briceño, J. 1999. "Quebrada Santa María: Las puntas en cola de pescado y la antigüedad del hombre en Sudamérica." Boletín de Arqueología PUCP 3: 19-40.

Capeletti, L. 2011. "Primer hallazgo de una punta de proyectil "cola de pescado' en la provincia de Entre Ríos." Revista del Museo de La Plata: Arqueología 12: 86.

Cardich, A., L. Cardich, and A. Hajduk. 1973. "Secuencia arqueológica y cronología radiocarbónica de la Cueva 3 de Los Toldos (Santa Cruz, Argentina)." Relaciones de la Sociedad Argentina de Antropología VII: 85-114.

- Chauchat, C., and J. Zevallos Quiñones. 1979. "Una punta cola de Pescado procedente de la Costa Norte del Perú." Ñawpa Pacha 17: 143-146.

Claraz, J. 1988. Diario de viaje de exploración al Chubut, 1865-1866. Buenos Aires: Ediciones Marymar.

Cooke, R. 1998. "Human settlement of Central America and northernmost South America (14,000-8000 BP)." Quaternary International 49/50: 177-190.

Criado Boado, F. 1993. "Visibilidad e interpretación del registro arqueológico." Trabajos de Prehistoria 50: 39-56.

Crivelli Montero, E. 2010. "Arqueología de la cuenca del Río Limay." In Los Ríos mesetarios norpatagónicos, edited by Masera Freddy and Juana Lew, 261-338. Río Negro province, Argentina: Fundación Ameghino.

Dillehay, T. 1997. Monte Verde: A Late Pleistocene Settlement in Chile. The Archaeological Context and Interpretation, Vol. 2. Washington, DC: Smithsonian Press.
Dillehay, T. 2010. "Un Enfoque Hacia la Organización SocioEspacial de Forrajeros Pleistocénicos Tardios: un caso del Perú $y$ sus implicancias más amplias." V Simposio El Hombre temprano en América. A cien años del debate: Ameghino-Hrdlicka. La Plata: Libro de Resúmenes.

Dillehay, T. 2011. From Foragers to Farmers: A New Perspective on Food Production and Social Organization. Cambridge: Cambridge University Press.

Ellis, C. 2009. "The Crowfield and Caradoc sites, Ontario: Glimpses of Palaeo-Indian sacred ritual and world view." In Painting the Past with a Broad Brush: Papers in Honour of James Valliere Wright, edited by D. L. Keenlyside and J.-L. Pilon, 319-352. Gatineau, Quebec: Canadian Museum of Civilization Mercury Series Paper.

Erlandson, J. M. 2001. "The archaeology of aquatic adaptations: Paradigms for a new millennium." Journal of Archaeological Research 9(4): 287-350.

Flegenheimer, N. 1980. "Hallazgos de puntas 'cola de pescado' en la Provincia de Buenos Aires." Relaciones de la Sociedad Argentina de Antropología XIV(1): 169-176.

Flegenheimer, N. 2003. "Cerro El Sombrero: A locality with a view." In Where the South Winds Blow: Ancient Evidence of Paleo South Americans, edited by L. Miotti, M. Salemme, and N. Flegenheimer, 57-61. College Station: Center for the Study of the First Americans, Texas A\&M University.

Flegenheimer, N. 2004. "Las ocupaciones de la transición Pleistoceno-Holoceno: Una visión sobre las investigaciones en los últimos 20 años en la Región pampeana." In $L a$ Arqueología uruguaya ante los desafios del nuevo siglo, CD edited by L. Beovide, I. Barreto, and C. Curbelo. Uruguay.

Flegenheimer, N., and C. Bayón. 1999. "Abastecimiento de rocas en sitios pampeanos tempranos: Recolectando colores." In Los Tres Reinos: Prácticas de Recolección en el Cono Sur de América, edited by C. Aschero, M. Kostanje, and P. Vuoto, 95-107. Instituto de Arqueología y Museo FCN e IML-UNT. Tucumán: Ediciones Magna Publicaciones.

Flegenheimer, N., C. Bayón, M. Valente, J. Baeza, and J. Femenías. 2003. "Long distance tool stone transport in the Argentine Pampas." Quaternary International 109-110: 65-76.

Flegenheimer, N., N. Mazzia, and M. P. Babot. 2013. "Estudios de usos y recursos sobre una piedra discoidal pampeana." Revista Intersecciones 14-2: 499-505. Olavarría: FACSOUNICEN.

Flegenheimer, N., N. Mazzia, and C. Weitzel, 2015. "Landscape and rocks in the east-central portion of the Tandilia Range (Buenos Aires Province, Argentina)." PaleoAmerica 1: 163-180.

Flegenheimer, N., and M. Zarate. 1997. "Considerations on radiocarbon and calibrated dates from Cerro La China and Cerro El Sombrero, Argentina." Current Research in the Pleistocene 14: 27-28.

Franco, Nora V. 2002. “Es posible diferenciar los conjuntos líticos atribuídos a la exploración del espacio de los correspondientes a otras etapas del poblamiento?." Werken 3: 119-132.

Frison, G. 1990. "The North American High Plains Paleoindian: An overview." Revista de Arqueología Americana. Journal of American Archaeology 2: 9-54. Instituto Panamericano de Geografía e Historia.

G. Frison, and L. Todd, eds. 1987. The Horner Site. The Type Site of the Cody Cultural Complex. New York: Academic Press.

Frison, G. C., and B. A. Bradley. 1999. The Fenn Cache: Clovis Weapons and Tools. Santa Fe: One Horse Land and Cattle Company.

Gamble, C. 1993. "People on the move: Interpretations of regional variation in Palaeolithic Europe." In Cultural Transformations and Interactions in Eastern Europe, edited by J. Chapman and P. Dolukhanov, 37-55. London: Avebury.

Gamble, C., and O. Soffer 1990. "Pleistocene polyphony: The diversity of human adaptations at the Last Glacial Maximum." In The World at 18,000 BP, Vol. 1, edited by O. Soffer and C. Gamble, 3-38. New York: Unwin Hyman.

Garcia, A. 2003. "La ocupación temprana de Los Andes Centrales Argentinos (ca. 11.000-8.000 años C14 AP).” Relaciones 28: $153-165$.

Goebel, T., B. Hockett, K. Adams, D. Rhode, and K. Graf. 2011. "Climate, environment, and humans in North America's Great Basin during the Younger Dryas, 12,900-11,600 calendar years ago." Quaternary International 242: 479-501. 
Grigor'ev, G. 1993. "The Kostenki-Avdeevo archaeological culture and the Willendorf-Pavlov-Kostenki-Avdeevo cultural unity." In From Kostenki to Clovis: Upper Paleolithic-Paleo-Indians Adaptations, edited by O. Soffer and N. D. Praslov, 51-66. New York: Plenum.

Grosjean, M., L. Nuñez, and I. Cartajena 2005. "Palaeoindian occupation of the Atacama Desert, northern Chile." Quaternary International 20: 643-653.

Gruhn, R., and A. L. Bryan. 1977. "Los Tapiales: A Paleo-Indian campsite in the Guatemala highlands." Proceedings of the American Philosophical Society 121(3): 235-273.

Hermo, D., and E. Terranova. 2012. "Formal variability in Fishtail projectile points of Amigo Oeste archaeological site, Plateau (Río Negro, Argentina)." In Southbound: Late Pleistocene Peopling of Latin America, edited by L. Miotti, N. Flegenheimer, M. Salemme, and T. Goebel, 121-127. College Station: Center for the Study of the First Americans, Texas A\&M University.

Hermo, D., E. Terranova, L. Marchionni, L. Magnin, B. Mosquera, and L. Miotti. 2013a. "Piedras o litos discoidales en Norpatagonia: Evidencias en la Meseta de Somuncurá (Río Negro, Argentina)." Revista Intersecciones 14(2): 507-511. Olavarría: FACSO-UNICEN.

Hermo, D., E. Terranova, B. Mosquera, and J. Frutos. 2013b. "Base regional de recursos líticos en la Meseta de Somuncurá: Primeros resultados en la cuenca del Arroyo Talagapa (Río Negro, Argentina)." In Tendencias teórico-metodológicas y casos de estudio en la arqueología de Patagonia, edited by A. F. Zangrando, R. Barberena, A. Gil, G. Neme, M. Giardina, L. Luna, C. Otaola, S. Paulides, L. Salgán, and A. Tivoli, 109-118. Buenos Aires: Sociedad Argentina de Antropologia, Instituto Nacional de Antropologia y Pensamiento Latinoamericano, Museo de Historia Natural de San Rafael.

Hoganson, J., and A. Ashworth. 1993. "The magnitude and the rapidity of the climate change marking the end of the Pleistocene in mid-latitudes of South America." Palaeogeography, Palaeoclimatology, Palaeoecology 101: 263-270.

Holliday, V., G. Martínez, E. Johnson, and B. Buchanan. 2003. "Geoarchaeology of Paso Otero 5 (Pampas of Argentina)." In From Where the South Winds Blow: Ancient Evidence for Paleo South Americans, edited by L. Miotti, M. Salemme, and N. Flegenheimer, 37-43. College Station: Center for the Study of First Americans, Texas A\&M University.

Ingold, T. 1986. The Appropriation of Nature. Essays on Human Ecology and Social Relations. Cambridge: Manchester University Press.

Instituto Geográfico Militar 1986 [map]. "Carta topográfica Maquinchao (Río Negro).” Hoja 4169-IV, escala 1:250000. Compilación IGM 1986. Buenos Aires, Argentina.

Jackson, D., and Méndez. 2007. "Litos discoidales tempranos en contextos paleoindios de Sudamérica." Magallania 35(1): 75-84.

Laguens, A. 2009. "De la Diáspora al Laberinto: Notas y reflexiones sobre la dinámica relacional del poblamineto humano en el centro-sur de Sudamérica." Revista de Arqueología Suramericana 5(1): 42-67. Bogotá-Catamarca.

Laguens, A., R. Cattáneo, E. Pautassi, and G. Sario. 2007. "ELS1, a Fishtail projectile-point site from central Argentina." Current Research in the Pleistocene 24: 55-57.

Lassen, R. 2005. A Comparison of Clovis Caches. MA thesis, Department of Anthropology, Texas A\&M University, College Station.

Latour, B. 1996. "On actor-network theory. A few clarifications plus more than a few complications." Soziale Welt 47: 369-381. Germany.

Law, J. 1992. "Notes on the Theory of the Actor Network: Ordering, Strategy and Heterogeneity." Systems Practice 5: 379-393.

Leon, M. 2006. "A new fluted Fishtail point find from Costa Rica." Mammoth Trumpet 21(3): 1-2, 20.

Martínez, G. 2001. "'Fish-tail' projectile points and megamammals: New evidence from Paso Otero 5 (Argentina)." Antiquity 75: 523-528.

Martínez, G. 2006. "Arqueología del curso medio del río Quequén Grande: estado actual y aportes a las arqueologías de la Región Pampeana." Relaciones de la Sociedad Argentina de Antropología XXXI: 249-275.
Masera, R. (coordinador) 1998. La Meseta patagónica del Somuncura. Un horizonte en movimiento. Carmen de Patagones: Gobiernos de la provincia de Chubut y Río Negro.

Massone, M. 2003. "Fell 1 hunters' fire hearths in Magallanes area by the end of the Pleistocene." In From Where the South Winds Blow: Ancient Evidence for Paleo South Americans, edited by L. Miotti, M. Salemme, and N. Flegenheimer, 153-159. College Station: Center for the Study of the First Americans, Texas A\&M University.

Massone, M. 2004. "Los cazadores después del hielo." In Colección de Antropología, edited by Marcelo Rojas. Santiago: Centro de Investigaciones Diego Barros Arana.

Mayer-Oakes, W. J. 1966. "El Inga projectile points - Surface collections." American Antiquity 31(5): 644-661.

Mayer-Oakes, W. J. 1986. "El Inga: A Paleo-Indian site in the sierra of northern Ecuador." Transactions of the American Philosophical Society 76(4): 1-235. Philadelphia.

Mazzanti, D. 2003. "Human settlements in caves and rockshelters during the Pleistocene-Holocene transition in the eastern Tandilia Range, Pampean region, Argentina." In From Where the South Winds Blow: Ancient Evidence for Paleo South Americans, edited by L. Miotti, M. Salemme, and N. Flegenheimer, 57-62. College Station: Center for the Study of First Americans, Texas A\&M University.

Mazzia, N. 2011. Lugares y paisajes de cazadores recolectores en la pampa bonaerense: cambios y continuidades durante el Pleistoceno final- Holoceno. PhD dissertation, Facultad de Ciencias Naturales y Museo, Universidad Nacional de La Plata.

Mazzia, N., and N. Flegenheimer. 2012. "Early settlers and their places in the Tandilia Range (Pampean region, Argentina)." In Southbound: Late Pleistocene Peopling of Latin America, edited by L. Miotti, M. Salemme, N. Flegenheimer, and T. Goebel, 105-111. College Station: Center for the Study of the First Americans, Texas A\&M University.

Meltzer, D. 2003. "Lessons in landscape learning." In Colonization of Unfamiliar Landscapes: The Archaeology of Adaptation, edited by M. Rockman and J. Steele, 222-241. London: Routledge.

Mendez, C., D. Jackson, R. Seguel, and A. Nuevo Delaunay. 2010. "Early high-quality lithic procurement in the semiarid north of Chile." Current Research in the Pleistocene 27: 19-21.

Meneghin, H. 2011. "Observaciones sobre algunos artefactos líticos discoidales registrados en el Uruguay." Orígenes 10: 1-32. Montevideo, Uruguay: Fundación Arqueología Uruguaya.

Messineo, P., G. Politis, and C. Kaufman. 2005. "Persistencia ritual entre cazadores-recolectores de la Llanura Pampeana." Boletín de arqueología 9: 67-90. PUCP, Perú.

Miller, E. T. 1987. "Pesquisas arqueológicas Paleoíndias no Brasil occidental in investigaciones Paleoíndias de la línea Equatorial." Colección Estudios Atacameños 8: 37-61.

Miotti, L. 1995. "Piedra Museo locality: A special place in the New World." Current Research in the Pleistocene 12: 37-40.

Miotti, L. 1996. "Piedra Museo (Santa Cruz): nuevos datos para el debate de la ocupación Pleistocénica en Patagonia." In Arqueología, sólo Patagonia, edited by J. Gómez Otero, 27-38. Argentina: Publicación Secretaría de Cultura de Chubut y CONICET.

Miotti, L. 1998. Zooarqueologia de la meseta central y costa de la provincia de Santa Cruz: Un enfoque de las estrategias adaptativas aborígenes y los paleoambientes. Edición especial del Museo Municipal de Historia Natural de San Rafael, Mendoza (edited by Humberto Lagiglia).

Miotti, L. 2003. "South America. A paradox for building images of the colonization of the New World." Quaternary International 109-110: 147-173.

Miotti, L. 2006. "La fachada atlántica, como puerta de ingreso alternativa de la colonización humana de América del sur durante la transición Pleistoceno/Holoceno.” In II Simposio Internacional El Hombre Temprano en América, edited by J. C. Jiménez and S. González, 155-188. México City: INAH (México), Museo del Desierto de Coahuila, UNAM.

Miotti, L. 2008. "Household and sacred landscapes among Holocene hunter-gatherers of Patagonia's Central Plateau." Before Farming 3: 5-44.

Miotti, L. 2010a. "La señal arqueológica de colonización Finipleistocénica y la continuidad ocupacional en la meseta de Somuncurá, Prov. De Río Negro, Argentina." In Arqueología Argentina en el Bicentenario de la Revolución, 
Tomo V, edited by R. Bárcena, and H. Chiavazza, 1951-1956. Mendoza.

Miotti, L. 2010b. "El rol del litoral marítimo y los ríos en la colonización humana de Patagonia desde finales de la Edad del Hielo. Una historia de más de 11.000 años.” In Los Ríos Mesetarios Norpatagónicos: Aguas Generosas del Ande al Atlántico, edited by R. Masera and Juana Lew, 95-193. Las Mesetas Patagónicas del estado de Río Negro. Río Negro province, Argentina: Fundación Ameghino.

Miotti, L., R. Blanco, E. Terranova, D. Hermo, and B. Mosquera. 2009. "Paisajes y Cazadores recolectores. Localidades arqueológicas de Plan Luan y cuenca inferior del arroyo Talagapa." In Arqueología de la Patagonia. Una mirada desde el último confin, edited by M. Salemme, E. Piana, M. Alvarez, F. Santiago, M. Vázquez, and E. Mansur, 265-280. Ushuaia, Tierra del Fuego: Editorial Utopías.

Miotti, L., F. Brittez, and M. J. Canosa. 1996. Informe sobre Nuevas prospecciones en Cerro Vanguardia. Marzo 1996. Informe de Asesoría Científica para Consultora Ambiental S.A. and Knithpiedsol Inc.

Miotti, L., D. Hermo, R. Blanco, and E. Terranova. 2010a. "Puntas cola de pescado en el ecorefugio de la meseta de Somuncurá Río Negro, Argentina." In IV Tomo El Hombre temprano en América, edited by J. C. Jiménez, 149-172. Mexico City: Publicaciones INAH.

Miotti, L., D. Hermo, R. Blanco, and E. Terranova. 2011. "Puntas cola de pescado en el ecorefugio de la meseta de Somuncurá Río Negro, Argentina." In IV Tomo El Hombre temprano en América, edited by J. C. Jiménez, 149-172. México City: Publicaciones INAH, UNAM, Museo del Desierto.

Miotti, L., D. Hermo, and E. Terranova. 2010b. "Fishtail points, first evidence of late Pleistocene hunter-gatherers in Somuncurá Plateau (Rio Negro Province, Argentina)." Current Research in the Pleistocene 27: 22-24.

Miotti, L., M. Salemme, D. Hermo, L. Magnin, and J. Rabassa. 2004. "Yamnago 137 años después: otro lenguaje para la misma región." In Contra viento y marea: arqueología de Patagonia, edited by M. T Civalero, P. Fernández, and G. Guráieb, 775-796. Buenos Aires, Argentina.

Miotti, L., and E. Terranova. 2010. "Cerro el Amigo Oeste, un nodo en la red de comunicación social finipleistocénica en Sudamérica." Paper presented at V Simposio Internacional 'El Hombre Temprano en América: a cien años del debate Ameghino-Hrdlicka (1910-2010)', La Plata, Buenos Aires, November 22-26.

Miotti, L., and E. Terranova. 2011. "Overcrowded Hill Points in the Terra Incognita Patagonia." Paper presented at 'Networks among Early South Americans,' XVI UISPP conference, Florianópolis, Brazil, September 4-10.

Miotti, L., E. Terranova, R. Barberena, D. Hermo, M. Giesso, and M. Glascock. 2012. "Geochemical sourcing of obsidian Fishtail points: Studies for the Somuncura Plateau (Río Negro, Argentina)." In Southbound: Late Pleistocene Peopling of Latin America, edited by L. Miotti, M. Salemme, N. Flegenheimer, and T. Goebel, 127-132. College Station: Center for the Study of the First Americans, Texas A\&M University.

Miotti, L., M. Vázquez, and D. Hermo. 1999. "Piedra Museo: un Yamnago pleistocénico de los colonizadores de la meseta de Santa Cruz. El estudio de la arqueofauna." In Soplando en el Viento, Arqueología de la Patagonia, edited by J. Gómez Otero, 113-135. Neuquén and Buenos Aires: CONICETINAPL.

Moreno, F. P. n.d. Recuerdos de un viaje a Nahuel Huapi. El llano de Yamnagoo. Visita a los Gennaken. Una raza que muere. Mecanografiado.

Mujica, J. 1995. "Puntas cola de pescado de la costa occidental del río Uruguay medio, litoral argentino." Comechingonia 8: 199-207.

Nami, H. 1987. "Cueva del Medio: Perspectivas arqueológicas para la Patagonia Austral." Anales del Instituto de la Patagonia (Serie Ciencias Sociales) 17: 71-106. Punta Arenas, Chile.

Nami, H. 1992. "Nuevos datos en relación a las puntas de proyectil paleoindias encontradas en el cono sur (Neuquén, Argentina). Palimpsesto." Revista de arqueología 1: 71-74. Buenos Aires.

Nami, H. 1999. "Arqueología en la localidad arqueológica de pali aike, cuenca del rio chico (santa cruz, argentina)." Prehistoria 3: 22-37. Buenos Aires.
Nami, H. 2007. "Research in the Middle Negro River Basin (Uruguay) and the Paleoindian occupation of the Southern Cone." Current Anthropology 48(1): 164-174.

Nami, H. 2009. "Crystal quartz and Fishtail projectile points: Consideration of raw-material selection by Paleo South Americans." Current Research in the Pleistocene 26: 9-12.

Nami, H. 2011. "Tecnología Paleoindia de Sudamérica: Nuevos experimentos y observaciones para investigar la secuencia de reducción Fell." Orígenes 9, 1-16. Montevideo, Uruguay: Fundación Arqueología Uruguaya.

Nuñez, L., J. Varela, R. Casamiquela, V. Schiappacasse, H. Niemeyer, and C. Villagran. 1994. "Cuenca de Taguatagua en Chile: El ambiente del Pleistoceno superior y ocupaciones humanas." Revista Chilena de Historia Natural 67: 503-519.

Nuñez Atencio, L., M. Grosjean, and I. Cartajena. 2005. Ocupaciones humanas y paleoambientes en la Puna de Atacama. Universidad Católica del Norte. San Pedro de Atacama, Taraxacum.

Núñez Atencio, L., J. Varela, R. Casamiquela, V. Schiappacasse, H. Niemeyer, and C. Villagrán 1994. "Cuenca de Taguatagua en Chile: El ambiente del Pleistoceno superior y ocupaciones humanas." Revista Chilena de Historia Natural 67: 503-519. Chile.

Ossa, J. 1976. "A fluted 'Fish-tail' projectile point from La Cumbre, Moche Valley." Nawpa Pacha 13: 97-98.

Politis, G. 1991. "Fishtail projectile points in the Southern Cone of South America: An overview." In Clovis: Origins and Adaptations, edited by R. Bonnichsen and K. L. Turnmire, 287-303. Corvallis: Center for the Study of the First Americans, Oregon State University.

Politis, G. 1998. "Arqueología de la Infancia: una perspectiva etnoarqueológica." Trabajos de Prehistoria 55(2): 5-19. Madrid.

Prieto, A. 1991. "Cazadores tempranos y tardíos en cueva del Lago Sofia 1." Anales del Instituto de la Patagonia, Serie Ciencias Humanas 20: 75-99. Punta Arenas, Chile.

Prous, A., and E. Fogaça. 1999. "Archaeology of the Pleistocene-Holocene boundary in Brazil." Quaternary International 53-54: 21-41.

J. Rabassa ed. 2008. The Late Cenozoic of Patagonia and Tierra del Fuego. New York: Elsevier.

Remesal, M., F. Salani, M. Franchi, and A. Ardolino. 2001. "Hoja Geológica 4169-IV, Maquinchao. Provincia de Río Negro." Instituto de Geología y Recursos Minerales, Servicio Geológico Minero Argentino, Boletín 312: 1-72. Buenos Aires.

Rockman, M. 2003. "Knowledge and learning in the archaeology of colonization." In Colonization of Unfamiliar Landscapes: The Archaeology of Adaptation, edited by M. Rockman and J. Steele, 3-24. London: Routledge.

Saunders, N. 2004. "The cosmic earth. Materiality and mineralogy in the Americas." In Soils, Stones and Symbols: Cultural Perceptions of the Mineral World, edited by N. Boivin and M. A. Owoc, 123-142. London: UCL Press.

Shobinger, J. 1957. "Arqueología de la Provincia del Neuquen." Estudios de los hallazgos moviliares. Anales de Arqueología y Etnologia XIII(5): 5-238.

Smith Dias, A. 2012. "Hunter-gatherer occupation of south Brazilian Atlantic forest: Paleoenvironment and archaeology." Quaternary International 256: 12-18.

Snarskis, M. 1979. "Turrialba: A Paleo-Indian quarry and workshop site in eastern Costa Rica." American Antiquity 44(1): 125-137.

Soffer, O., and C. Gamble, eds. 1990. The World at 18,000 BP, vol. 1, High Latitudes. London: Unwin Hyman.

Soffer, O., and N. Praslov 1993. "Introduction: Fluted points and female figurines-Understanding Late Paleolithic people of the New and Old Worlds." In From Kostenki to Clovis: Upper Paleolithic-Paleo-Indians Adaptations, edited by O. Soffer and N. D. Praslov, 3-14. New York: Plenum.

Storck, P. 1991. "Imperialists without a state: The cultural dynamics of early Paleoindian colonization as seen from the Great Lakes region." In Clovis: Origins and Adaptations, edited by R. Bonnichsen and K. Turnmire, 153-162. Corvallis: Center for the Study of the First Americans, Oregon State University Press.

Suárez, R. 2011. Arqueología durante la Transición Pleistoceno Holoceno: Componentes Paleoindios, Organización de la Tecnología y Movilidad de los Primeros Americanos en Uruguay. British Archaeological Research, BAR International Series. Oxford Archaeopress.

Taçon, P. 1991. "The power of stone: Symbolic aspects of stone use and tool development in Western Arnhem Land, Australia." Antiquity 65: 192-207. 
Terranova, E. 2013. "Prospecciones en la Meseta de Somuncurá. Primeros resultados en la cuenca media y alta del arroyo Talagapa." In Tendencias teórico-metodológicas y casos de estudio en la arqueología de Patagonia, edited by A. F. Zangrando, R. Barberena, A. Gil, G. Neme, M. Giardina, L. Luna, C. Otaola, S. Paulides, L. Salgán, and A. Tivoli, 139-144. Buenos Aires, Argentina: Instituto Nacional de Antropología y Pensamiento Latinoamericano, Museo de Historia Natural de San Rafael.

Terranova, E., R. V. Blanco, L. Marchionni, and L. Miotti. 2010. "Un lugar especial en el mundo: Arqueología en la Meseta de Somuncurá. Una punta para el poblamiento americano." Revista Museo 3(24): 75-81.

Tolan-Smith, Charles 1998. "Radiocarbon chronology and the lateglacial and early postglacial resettlement of the British Isles." Quaternary International 49/50: 21-27.

Torrence, R. 2005. "Valued stone: How so?" In Many Exchanges: Archaeology, History, Community and the Work of Isabel McBryde, edited by I. MacFarlane, R. Paton, and M. Mountain, 357-372. Aboriginal History Monograph 11.

Torrence, R. 2011. "Finding the right question: Learning from stone tools on the Willaumez Peninsula, Papua New Guinea." Archaeology in Oceania 46: 29-41.

Vilca, M. 2011. "Piedras que hablan, gente que escucha: la experiencia del espacio andino como un «otro» que interpela. Una reflexión filosófica." In Biografías de paisajes y seres. Visiones desde la arqueología sudamericana, edited by D. Hermo and L. Miotti, 67-74. Córdoba: Grupo Editorial Encuentro.
Walker, W. 1995. "Ceremonial trash?" In Expanding Archaeology, edited by J. Skibo, W. Walker, and A. Nielsen, 67-79. Salt Lake City: University of Utah Press.

Webb, E. 2010. "The Mode and Tempo of the Initial Colonization of Empty Landmasses by Gatherer-Hunters: Sahul (Greater Australia) and the Americas Compared." Paper presented at the V International Symposium of Early Man in America, November 22-26. Book of Abstracts, 133. La Plata: University of La Plata.

Weitzel, C. 2012. Broken stone tools from Cerro El Sombrero Cima (Tandilia Range, Argentina). In Southbound: Late Pleistocene Peopling of Latin America, edited by L. Miotti, M. Salemme, N. Flegenheimer, and T. Goebel, 111-115. College Station: Center for the Study of the First Americans, Texas A\&M University.

Weitzel, C. 2010. El estudio de los artefactos formatizados fracturados. Contribución a la comprensión del registro arqueológico y las actividades humanas. $\mathrm{PhD}$ dissertation, Facultad de Filosofía y Letras, Universidad de Buenos Aires, Buenos Aires.

Whallon, R. 2006. "Social networks and information: Non utilitarian mobility among hunter-gatherers." Journal of Anthropological Archaeology 25: 259-270.

Willig, J. A. 1991. "Clovis technology and adaptation in far western North America: Regional pattern and environmental context." In Clovis Origins and Adaptations, edited by R. Bonnichsen and K. L. Turnmire, 91-119. Corvallis: Center for the Study of the First Americans, Oregon State University.

\section{Author's Biographies}

Laura Miotti earned her PhD in Natural Sciences (Anthropology focus) in 1990. Since 2004, she has held the position of professor of American Archeology 1 (foraging and farming societies), UNLP. Her research interests include the archeology of colonization and Patagonia, the specific area where she carries out fieldwork. Since 1992, she has been a researcher of CONICET.

Enrique Terranova obtained his PhD in Natural Sciences (Anthropology focus) in 2013. Since 2008, he has held the position of assistant professor of Anthropology, UNLP. His research interests include the archeology of colonization, and his research area is Patagonia. He has been a fellow of CONICET since 2008. 